\title{
Implementation of East African Community Law by Partner States: A review of relevant laws
}

Augustus Mutemi Mbila *

\section{Abstract}

On 30 November 1999, the Heads of State of the East African Community met in Arusha, Tanzania, and concluded the Treaty for the establishment of the East African Community. The Treaty came into force on 7 fuly 2000. The founding members of this Community were Kenya, Uganda, and Tanzania. Rwanda and Burundi acceded to the Treaty in 2007 while South Sudan acceded to the Treaty in 2016. While the treaty has the potential of promoting unity among the partner states, this is threatened by the fact that it fails to address how Partner States should implement it. A critical analysis of the jurisprudence from the East African Court of Fustice and those of the Court of Fustice of the European Union shows that community law is an autonomous legal order in which Partner States have accepted to cede part of their sovereignty to the community. Therefore, community law, unlike international law which houses it, has primacy over the municipal law of the Partner States, notwithstanding their constitutional philosophies. This paper seeks to examine how East African Community Law is implemented by partner states by reviewing the EAC Treaty, the decisions of the East African Court of Fustice and the municipal laws of partner states. Decisions of the Court of Fustice of the European Union on the implementation of European Union Law by Partner States of the European Union are discussed as lessons to be learnt in the East African Community.

Key Words: East African Community law, East African Court of Justice and Court of Justice of the European Union

* The author completed his LLM programme at the University of Dar es salaam. 


\section{Introduction}

The Treaty for the Establishment of the East African Community, 1999 ('the EAC Treaty') was concluded to strengthen the economic, social, cultural, political, technological and other ties of the Partner States for their balanced and sustainable development. ${ }^{1}$ The objectives of the Community are listed in Article 5 of the Treaty as: attaining the sustainable growth of the Partner States, strengthening and consolidating cooperation of the Partner States in agreed fields to promote economic development, promoting the sustainable utilisation of natural resources, strengthening political, economic, social, cultural and traditional ties, and promoting peace, security and stability in the region. ${ }^{2}$

Article 2 of the Treaty requires Partner States to 'secure the enactment and the effective implementation of such legislation as is necessary to give effect' to the EAC Treaty within twelve months from the date of signing the treaty. For this reason, Partner States have Acts of Parliament domesticating the EAC Treaty in their legal systems. The Republic of Kenya has The Treaty for the Establishment of the East African Community Act, ${ }^{3}$ The Republic of Uganda has The East African Community Act, 2002, while the United Republic of Tanzania has the Treaty for the Establishment of the East African Community Act, 2001. These are the three founding members of the East African Community. The Republics of Rwanda, Burundi and South Sudan acceded to the EAC Treaty much later. ${ }^{4}$ Although the EAC Treaty stipulates how the Treaty itself will be implemented in the legal systems of the Partner States, the Partner States have their individualised approaches towards implementing international law, in which regional integration law is housed. These approaches are likely to impede the implementation of the EAC Treaty and decisions of organs of the Community.

This paper seeks to review these EAC Partner States' approaches towards implementing international law and the impact of the approaches on the implementation of EAC Law. The review will highlight the challenges that characterise the implementation of EAC Law by Partner States. The paper starts by analysing the lessons that the EAC can learn from the European Union (EU), based on the important principles of Community Law that the Court of Justice of the European Union (CJEU) has developed over time. Decisions of

\footnotetext{
Preamble, Treaty for the Establishment of the East African Community (1999).

Article 5, EAC Treaty.

The Treaty for the Establishment of the East African Community Act (Act No 2 of 2000).

Rwanda and Burundi acceded to the EAC Treaty on June 18, 2007 and became full members on July $1,2007$.
} 
the East African Court of Justice and those of courts of Partner States will also be reviewed. Most importantly, the decisions of national laws of Partner States relating to the implementation of East African Community Law will also be analysed.

\section{The Nature of Community Law: Lessons from the European Union}

The EU has its origin in the European Coal and Steel Community (ECSC) and the European Economic Community (EEC) established, respectively, by the 1951 Treaty of Paris and 1957 Treaty of Rome. The EU has successfully established a customs union, a common market, and a monetary union. Border controls have also been effectively abolished to enhance free movement of persons within the region. The use of the Euro ensures that traders do not have to convert their currency every time they enter a new country that is a member of the EU. The use of the Schengen Visa also ensures that travelling to the Schengen Area is easy as citizens of countries forming the Schengen Area do not have to apply for a visa every time they intend to travel to a country in that area. The EAC, can, therefore, learn lessons from the EU as will be outlined in this section of the paper.

Community law falls under international law because Regional Economic Communities (hereinafter 'RECs') are creatures of treaties. ${ }^{5}$ Those treaties are interpreted according to the provisions of the Vienna Convention on the Law of Treaties (VCLT). ${ }^{6}$ Member states establish RECs by concluding treaties as the main constituting documents. ${ }^{7}$ These treaties outline the objectives of the RECs, obligations of member states, and organs of the RECs, among other components.

The East African Community is an example of a REC, which is established by the Treaty Establishing the East African Community of 1999. The European Union, on the other hand, is established by the Treaty on the Functioning of the European Union. All these treaties are to be interpreted as per the provisions

Oppong R F, Legal Aspects of Economic Integration in Africa, Cambridge University Press, Cambridge, 2011, 10.

Vienna convention on the law of treaties, 23 May 1969, 1155 UNTS 331.

Gathii J, African Regional Trade Agreements as Legal Regimes, Cambridge University Press, Cambridge, 2011, 7 . 
of the VCLT. This has been affirmed by the courts in a number of scenarios. For example, in The matter of a request by the council of ministers of the East African Community for an advisory opinion, ${ }^{8}$ the East African Court of Justice (EACJ) applied Article 31 of the VCLT to hold that the EAC Treaty must be interpreted in good faith. This is in line with the principle of pacta sunt servanda. ${ }^{9}$ Similarly, in the recent case of Media Council of Tanzania \& 2 others $v$ the Attorney General of the United Republic of Tanrania, ${ }^{10}$ the EACJ held that the EAC Treaty is an international instrument that should be construed in accordance with the provisions of the VCLT. Hence, the court will interpret the treaty that establishes the REC in the same way that it would interpret any other treaty.

RECs have been categorised as international or intergovernmental organisations. ${ }^{11}$ The main concern here is their legal personality/legal capacity. Can they be sued? Can they sue on their own behalf? Regarding the legal capacity of intergovernmental organisations, the case of Reparation of Injuries Suffered in Service of the $U N^{12}$ is authoritative. Here, the International Court of Justice (ICJ) held that the United Nations Organisation had legal capacity and that it could institute cases in the court on behalf of its members. The court held as follows:

'Accordingly, the Court has come to the conclusion that the Organisation is an international person. That is not the same thing as saying that it is a State, which it certainly is not, or that its legal personality and rights and duties are the same as those of a State. Still less is it the same thing as saying that it is 'a super-State', whatever that expression may mean. It does not even imply that all its rights and duties must be upon the international plane, any more than all the rights and duties of a State must be upon that plane. What it does mean is that it is a subject of international law and capable of possessing international rights and duties, and that it has capacity to maintain its rights by bringing international claims'. ${ }^{13}$

Ian Brownlie summarises the criteria for granting legal personality to an international organisation as follows:

i. A permanent association of states, with lawful objects, equipped with organs;

ii. A distinction, in terms of legal powers and purposes, between the organisation and its members; and

\footnotetext{
Application No. 1 of 2008.

Article 31, Vienna convention on the law of treaties, 23 May 1969, 1155 UNTS 331.

Reference No 2 of 2017.

Gathii J, African Regional Trade Agreements as Legal Regimes.

Reparation for injuries suffered in the service of the United Nations 174 (1949), Advisory Opinion, ICJ Reports 1949.

13 Reparation for injuries suffered in service to the United Nations, ICJ, 174.
} 
iii. The existence of legal powers exercisable on the international plane and not solely within the national systems of one or more states. ${ }^{14}$

The legal capacity of the EAC is granted by Article 4 of the Treaty. It states that 'the Community shall have the capacity, within each of the Partner States, of a body corporate with perpetual succession, and shall have power to acquire, hold, manage and dispose of land and other property, and to sue and be sued in its own name...'

The provisions of the instrument establishing the intergovernmental organisation are used to determine the intentions, the legal capacity and the objectives of the member states at the time of establishing the organisation. Thus, in Van Gend \& Loos, ${ }^{15}$ Tariefcommissie, an administrative tribunal in Netherlands, referred two questions for a preliminary ruling by the CJEU. The key question before the court for a preliminary ruling was whether Article 12 of the EEC Treaty had direct application within the territory of a Member State; in other words, whether nationals of such a State could, on the basis of the Article in question, lay claim to individual rights which the courts must protect.

Article 12 of the Treaty Establishing the EEC states as follows: 'Member States shall refrain from introducing, as between themselves, any new customs duties on importation or exportation or charges with equivalent effect and from increasing such duties or charges as they apply in their commercial relations with each other.' ${ }^{16}$

The court held as follows:

'To ascertain whether the provisions of an international treaty extend so far in their effects, it is necessary to consider the spirit, the general scheme and the wording of those provisions. The objective of the EEC Treaty, which is to establish a Common Market, the functioning of which is of direct concern to interested parties in the Community, implies that this Treaty is more than an agreement which merely creates mutual obligations between the contracting states. This view is confirmed by the preamble to the Treaty which refers not only to governments but to peoples. It is also confirmed more specifically by the establishment of institutions endowed with sovereign rights, the exercise of which affects Member States and also their citizens. Furthermore, it must be noted that the nationals of the states brought together in the Community are called upon to cooperate in the functioning of this Community through the intermediary of the European Parliament and the Economic and Social Committee'.

\footnotetext{
Brownlie I, Principles of international law, $5^{\text {th }}$ ed, 1966, 677.

Van Gen den Loos v Nederlandse Administratie der Belastingen (1963), European Court of Justice.

Article 12, Treaty Establishing the European Economic Treaty, 1957.
} 
Most importantly, the Court held that:

'The conclusion to be drawn from this, is that the Community constitutes a new legal order of international law for the benefit of which the states have limited their sovereign rights, albeit within limited fields, and the subjects of which comprise not only Member States but also their nationals. Independently of the legislation of Member States, Community law therefore not only imposes obligations on individuals but is also intended to confer upon them rights which become part of their legal heritage. These rights arise not only where they are expressly granted by the Treaty, but also by reason of obligations which the Treaty imposes in a clearly defined way upon individuals as well as upon the Member States and upon the institutions of the Community'.

The decision of the CJEU in this case summarises the nature of community law. This is a lesson that the EAC can learn as it seeks to establish a uniform set of rules that should govern its members. It follows that partner states of a REC decide to limit their sovereign rights in limited fields so that they agree to abide by the obligations that community law imposes upon them. These rights and obligations only arise where the member states have expressly or impliedly formed a REC that is supranational in nature. ${ }^{17}$ In cases where member states only intend to cooperate with each other in selected fields such as crime, politics, democratic governance and human rights, community law does not create such rights and obligations. ${ }^{18}$

Two years after the decision in Van Gen den Loos was issued, the CJEU was called upon to deliver another ruling regarding the supremacy of EU Law on the legal systems of the Partner States in the case of Flaminio Costa vs ENEL. ${ }^{19}$ The Court held that the Treaty of Rome created its own order which was integrated with the national order of the member states the moment the Treaty came into force. For this reason, the Treaty was binding on Partner States and that EU Law was superior to the municipal law of Partner States. ${ }^{20}$ This is another lesson that the EAC could learn from the EU: that the EAC Treaty is binding on Partner States and that the law emanating from the Treaty should be applied directly by Partner States judicial institutions.

Gathii J, African Regional Trade Agreements as Legal Regimes.

18 Kamanga, 'General principles governing EAC integration' in Ugirashebuja E, Ruhangisa J, Ottervanger T and Cuyvers A (eds) East African Community law: Institutional, substantive, and comparative aspects, Lieden, Boston: Brill, 2017, 34.

19 Flamino Costa v Enel (1964), European Court of Justice.

20 Kapteyn P J G, 'The application and enforcement of community law in national legal systems' in Kepteyn P J G, McDonnell A M, Morletlans K J M and Timmermans C W A (eds), $3^{\text {rd }}$ ed, The law of the European Union and the European Communities, 2008, 517. 
Regional integration law is well established under the instruments of the World Trade Organisation (WTO). Article XXIV of the General Agreement on Trade and Tariffs (GATT) recognises that WTO members are desirous of entering regional trade agreements to promote trade in their regions. The same Article further states that the purpose of establishing a customs union or a free trade area is to promote trade between the members of the union and not to add more barriers. ${ }^{21}$ The Enabling Clause on the other hand allows derogations to the most-favoured nation (non-discrimination) treatment in favour of developing countries. In particular, its paragraph 2(c) permits preferential arrangements among developing countries in goods trade. It has continued to apply as part of GAT'T 1994 under the WTO. ${ }^{22}$ Article V of the General Agreement on Trade in Services (GATS) is titled 'Economic Integration' and provides that the agreement does not prevent member states of the WTO from entering trade agreements whose intention is to liberalise trade between the members of that agreement.

Community law is, therefore, well anchored in international law. The East African Community is a REC that is targeting more than just trade liberalisation. Article 5(2) of the EAC Treaty states that one of the main objectives of the Community is to establish a Customs Union, a Common Market, a Monetary Union and, subsequently, a Political Federation in order to accelerate a harmonious economic growth in the EAC. ${ }^{23}$ For this reason, the EAC is gearing towards establishing a political federation, in addition to the three 'unions' that relate to trade. There is need for clarity regarding the effect of the law governing this federation as it will be implemented by Partner States in their national legal systems. Two lessons that the EAC can learn from the EU is that community law should be applied directly by Partner States and that, on matters relating to regional integration, community law is superior to the municipal law of Partner States.

An analysis of whether EAC law has a 'direct effect' on the Partner States or it must be domesticated in the legal systems of those Partner States is necessary.

Article XXIV, General Agreement on Tariffs and Trade, (1947).

22 World Trade Organisation, Differential and more favourable treatment reciprocity and fuller participation of developing countries, 1979.

23 Article 5(2), Treaty for the Establishment of the East African Community, (Act No. 2 of 2000). 


\section{The Nature and Effect of EAC Law on Partner States' Legal Systems}

Article 8 of the EAC Treaty outlines how the treaty should be implemented by Partner States. Community organs, institutions and laws shall take precedence over similar national ones on matters pertaining to the implementation of this Treaty. ${ }^{24}$ Partner States are required to make the necessary legal instruments to confer precedence of Community organs, institutions and laws over similar national ones. ${ }^{25}$ This means that for Community Law to take effect in the legal systems of Partner States, it has to be domesticated by legislation or other legal apparatus. However, on a closer look, this provision seems to be in conflict with Article 16 of the Treaty. The Article states that 'subject to the provisions of this Treaty, the regulations, directives and decisions of the Council taken or given in pursuance of the provisions of this Treaty shall be binding on the Partner States, on all organs and institutions of the Community other than the Summit, the Court and the Assembly within their jurisdictions, and on those to whom they may under this Treaty be addressed. ${ }^{26}$ This shows that the Treaty has taken a hybrid approach towards implementation. This hybrid approach is evidenced in the implementation of EAC Law by Partner States as discussed in later sections of this paper.

The nature and effect of EAC Law on Partner States' national legal systems can be derived from case law that has developed over time in the EACJ. In Prof Anyang' Nyong'o \& Others vs Attorney General of Kenya \& others, ${ }^{27}$ the applicant sought to challenge the procedure that the Republic of Kenya had followed in appointing the country's representatives to the East African Legislative Assembly (EALA). The members were simply selected and listed by the House Business Committee of the Kenyan National Assembly. This was contrary to Article 50(1) of the EAC Treaty which requires an actual election of members to represent each of the Partner States to the EALA. The Court noted that a country that binds itself to an international treaty may sometimes face conflicts when implementing such a treaty and at the same time implementing its municipal law. The Court proceeded to hold that a country that binds itself to such an international treaty cannot

Article 8(4), Treaty for the Establishment of the East African Community, (Act No. 2 of 2000).

Article 8(5), Treaty for the Establishment of the East African Community, (Act No. 2 of 2000).

The EAC Council of Ministers is established in Chapter Five of the Treaty as a policy-making organ of the Community

27 Professor Anyang' Nyong'o and others v Attorney General of Kenya and others, (2007) EACJ Reference No 1 of 2006. 
invoke its municipal law as a reason for its failure to implement the international treaty. ${ }^{28}$ The Court was also concerned that the Republic of Kenya could not simply nominate its members instead of conducting an election according to Article 50(1) of the Treaty. Doing so would lead to lack of uniformity in the Community; yet, Partner States have committed to harmonising all their national laws relating to the Community. ${ }^{29}$ In addition, the Court noted that by enacting the Treaty, Partner States of the EAC ceded part of their sovereignty to the Community in the spirit of promoting regional integration. In Flaminio Costa vs ENEL, discussed earlier, this was put forth in a manner that clearly stated the primacy of community law over municipal law.

Six years after the EACJ delivered its judgment in the Prof Anyang' Nyong'o case, another dispute between EAC Law and the law of a Partner State arose in the case of Samuel Mukira Muhochi vs Attorney General of Uganda, ${ }^{30}$ where a Kenyan national was denied entry by Ugandan officials upon arrival at Uganda's airport. The officials detained him and later deported him under the Uganda Citizen and Immigration Control Act. ${ }^{31}$ The officials argued that this had been done in pursuit of a security issue. The applicant argued that his freedom of movement as guaranteed under Article 104 of the EAC Treaty and Article 7 of the Protocol on the Establishment of the East African Common Market ('the Common Market Protocol') had been infringed. The Court held that, by enacting the East African Community Act, 2002; Uganda gave the Treaty legal force in its national legal order and that the Treaty was therefore directly enforceable in Uganda. For this reason, the wide-ranging rights that the Treaty accords all citizens of Partner States of the EAC were infringed by Ugandan officials.

The Republic of Uganda ratified the EAC Treaty without any reservations, which meant that the provisions of the entire treaty would have legal force in the country's legal order. It therefore meant that Uganda would no longer apply its national legislation regarding movement of citizens of EAC Partner States into the country. ${ }^{32}$ The country's legislation on immigration would only be applied on citizens of countries other than EAC Partner States. On this point,

Article 27, Vienna Convention on the Law of Treaties.

Article 126, Treaty for the Establishment of the East African Community, (Act No. 2 of 2000).

Samuel Mukira Mohochi v The Attorney General of the Republic of Uganda, (2013) EACJ Reference No. 5 of 2011.

31 Uganda Citizenship and Immigration Control Act, (1999).

32 For an in-depth analysis of the relationship between the Municipal Law of the EAC Partner States and EAC Law, see Sebijjo, E, Regional Integration Law in the East African Community and the European Union, Centre for Law, Economics and Policy on East African Integration, Kampala, 2018. 
the Treaty defines a foreign country as 'any country other than a Partner State'. ${ }^{33}$ By delivering this ruling, the Court concluded that EAC Law had precedence over national law in matters appurtenant to the East African Community. It was another case where the Court upheld the doctrine of supremacy of community law over municipal law on matters relating to the community. ${ }^{34}$ The Republic of Uganda therefore ceded part of its sovereignty to the EAC.

The EACJ also delivered a similar ruling in Burundian Journalists Union $v$ Attorney General of Burundi, ${ }^{35}$ where the Court held that certain sections of a recently enacted law in Burundi contravened Articles 6(d) and 7(2) of the EAC Treaty on fundamental principles and operational principles respectively, insofar as they curtailed freedom of expression. Similarly, in the Mukira Mubochi case, the EACJ held that the Republic of Burundi acceded to the EAC Treaty without reservations and that meant that it had ceded part of its sovereignty to the Community. For this reason, the country's parliament could not be allowed to enact a law that contravened provisions of the Treaty. This did not mean that the Court was superintending on the way in which state organs were carrying out their affairs. All it meant was that Partner States had an obligation to safeguard the Treaty that they acceded to willingly and without reservations. By delivering this ruling, the Court gave a teleological interpretation of Article 8(4) on the implementation of the EAC Treaty.

In the recent case of British American Tobacco (U) Limited $v$ The Attorney General of Uganda, ${ }^{36}$ the EACJ was called upon to make a determination as to whether custom duties imposed on a company domiciled in a Partner State of the EAC contravened the EAC Treaty and its protocols. In 2017, Uganda passed into law the Excise Duty (Amendment) Act, which imposed a higher excise duty on imported cigarettes than cigarettes manufactured in Uganda. Cigarettes imported by British American Tobacco (Uganda) Ltd from the company's sister company in Kenya were therefore categorised as having been imported from a 'foreign' country and would attract a higher excise duty. Until the enactment of the law, these goods had been categorised as locally manufactured goods. Uganda argued that this was done to promote local industries. The Treaty defines

\footnotetext{
Article 1, Treaty for the Establishment of the East African Community, (Act No. 2 of 2000).

Flamino Costa v ENEL (1964), European Court of Justice.

Burundian Journalists Union v Attorney General of Republic of Burundi (2018), East African Court of Justice Reference No. 7 of 2013.

36 British American Tobacco (U) Ltd v The Attorney General of the Republic of Uganda (2017), Reference No. 7 of 2017.
} 
a 'foreign country' as a country other than a Partner State. ${ }^{37}$ The EACJ held that, by categorising Kenya as a foreign country, Uganda violated the EAC Treaty and the Protocol on the Establishment of the East African Customs Union, 2004. The EACJ therefore construed the EAC Treaty and its protocols in a manner that promotes regional integration, while giving effect to EAC Law over domestic law.

In the 2017 case of Media Council of Tanzania and 2 Others v The Attorney General of the United Republic of Tanzania, ${ }^{38}$ the EACJ held that several sections of the Media Services Act ${ }^{39}$ violated the EAC Treaty as they infringed the right to freedom of expression. Three non-governmental organisations of the United Republic of Tanzania - the Media Council of Tanzania, Legal and Human Rights Centre, and Tanzania Human Rights Defenders Coalition - filed the reference as a result of concerns that the legislation's criminalisation of defamation, false news, and other media conduct, and restriction of media freedom infringed freedom of expression and media freedom in Tanzania.

The applicants further held that by restricting media freedom, the Act was in violation of the principles of democracy, rule of law, accountability, transparency and good governance which Tanzania committed to uphold by ratifying and domesticating the EAC Treaty. This was, therefore, a violation of articles 6(d), 7 and 8 of the EAC Treaty. The EACJ therefore declared Sections 7(3)(a), (b), (c), (d), (e), (f), (g), (h), (i) and (j); 19; 20; 21; 35; 36; 37; 38; 39; 40; 50; 52; 53; 54; 58; and 59 of the Act to be an infringement of the EAC Treaty and directed the government of Tanzania to 'take such measures as are necessary to bring the Media Services Act into compliance with the Treaty for the Establishment of the East African Community'. ${ }^{40}$ These bold assertions of the EACJ are reminiscent of the law-making assertions of the CJEU in Van Gend en Loos, regarding the direct applicability of European Union Law in the legal order of Partner States; and COSTA $v$ ENEL, regarding the supremacy of European Union Law over municipal law of Partner States.

The discussion outlined here refers to instances where municipal law or decisions of organs of Partner States infringed the provisions of the EAC Treaty. The discussion provided here appears to suggest that the EACJ has been relied upon as the final arbiter and decision-maker on matters regarding regional

Articles 2(2), 5(2) and 8(1)(c), Treaty for the Establishment of the East African Community, (Act No. 2 of 2000) and Article 1(1) Protocol on the Establishment of the East African Community Customs Union.

38 Media Council of Tanzania v Attorney General (2017), Reference No. 2 of 2017.

39 Media Services Act, (Act No. 120 of 2016).

40 Media Council of Tanzania v Attorney General (2017). 
integration in the EAC. This is the aim of Article 23 of the EAC Treaty, which establishes the EACJ as a judicial body that shall ensure the adherence to law in the interpretation and application of and compliance with this Treaty. It is also in line with the provisions of Article 8 of the EAC Treaty, which provides that on matters relating to regional integration, EAC Law will take precedence over the municipal law of Partner States. This is the recommended approach as it is in line with the nature of community law. A salient discussion on the provisions of municipal laws with regards to EAC law would suffice.

\section{Municipal Law of EAC Partner States: Monist and dualist Approaches}

International law does not direct states on how they are supposed to implement it. States, out of good faith and desire to maintain the comity of nations, are at liberty to determine how international norms and decisions should be implemented by their own legal, executive and judicial institutions. ${ }^{41}$ Through their municipal law, states will either expressly or by conduct outline how international norms would be implemented in their jurisdictions. The question of dualism and monism therefore comes to mind.

Dualism is also referred to as the pluralist perspective and posits that there can be no conflict between municipal law and international law because both categories of laws operate in different spheres. ${ }^{42}$ With international law, a perfect treaty can only apply in the international realm..$^{43}$ Municipal law, on the other hand, only applies within the boundaries of the state to govern relationship between the state and its citizens and among citizens. For an international treaty to be applied to govern the affairs of the state and its citizens, it has to be nationalised or domesticated by adopting the legal measures from the treaty into a national provision. ${ }^{44}$

Ratification is therefore not enough. The treaty has to be 'nationalised' by introducing it to the state's jurisdiction through a national legal instrument, for example, an Act of Parliament. ${ }^{45}$ Ratification is an act of consent to be bound by

\footnotetext{
Crawford J, Brownlie's Principles of public international law, $8^{\text {th }}$ ed, Oxford University Press, 2012.

Malanczuk P, Akehurst's Modern introduction to international law, Routledge, London, 1997.

Denza E, 'The relationship between international and national law' in International Law, $4^{\text {th }}$ ed, Oxford University Press, 2006, 412-440.

44 O'Connell D P, International law, $2^{\text {nd }}$ ed, Stevens and Sons, 1970.

45 Kasese A, International law, $2^{\text {nd }}$ ed, 2005, 214.
} 
the treaty. Such an act is usually defined by the treaty itself if the treaty requires signatories to exchange instruments or to deposit such instruments with the depositary, within a stated timeframe. ${ }^{46}$ Section 2 of Kenya's Treaty Making and Ratification Act of 2012 defines ratification as 'the international act by which the State signifies its consent to be bound by a treaty and includes acceptance, approval and accession where the treaty so provides'. ${ }^{47}$ This definition does not include the enactment of a national instrument to 'nationalise' the treaty.

Monism is anchored on state sovereignty as an absolute dogma. ${ }^{48}$ A state willingly establishes relationships with other states, and by so doing allows itself to be governed by international law. ${ }^{49}$ Monism turns international law into a 'simple foreign law ${ }^{50}$ Based on this approach, both municipal and international law have a convergence and international law rules can influence municipal law rules. The international treaties that a state has ratified need not be 'nationalised' through a domestic instrument. In pure monist systems, the international treaty has an automatic effect on the national legal order once the state ratifies it. A national judge can therefore directly apply international law, and citizens can directly pursue their rights through international treaties. In Germany, for example, international law has the same effect as legislation and can be implemented directly without the need for a domestic instrument being enacted to implement it. ${ }^{51}$

None of the EAC Partner States has a clause in their national constitutions that provides expressly for the nature, effect and implementation of EAC Law in their national legal order. Yet, some of the states have promulgated their constitutions long after the conclusion of the EAC Treaty. ${ }^{52}$ The newest constitutional dispensation in the region, that of the United Republic of Tanzania, does not say anything either about the effect of EAC Law on Tanzania's legal order. ${ }^{53}$ The Constitution of the Republic of Uganda, however, has a provision on promoting regional and pan-African cultural, economic and political cooperation and integration. ${ }^{54}$ The founding Partner States, however,

\footnotetext{
46 Articles 2(1)(b), 14(1), 16, Vienna convention on the law of treaties, 23 May 1969, 1155 UNTS 331.

47 Section 2, Treaty Making and Ratification Act (Act No 45 of 2012).

48 Denza E, 'The relationship between international and national law' in International Law, 4th ed, Oxford University Press, 2006, 412-440.

49 Kelsen H, Principles of international law, $2^{\text {nd }}$ ed, 1967, 569.

50 Dixon M, Textbook on International Law, $6^{\text {th }}$ ed, Oxford University Press, 2008, 88.

51 Eichberger M, 'Monism or dualism?' 53 La Revue Administrative 2, 2000, 10-17.

52 For example, Kenya promulgated the new constitution in 2010.

53 Gastorn K, 'The East African Community and the Sovereignty Relinquishment Trail in the Constitution Making Process of Tanzania', Nyerere Law Journal (2014), 52.

54 Article XXVIII, Constitution of the Republic of Uganda (1995).
} 
have statutes domesticating the EAC Treaty in their national legal order. The manner in which each partner state implements EAC Law is discussed below.

\section{i. The Republic of Kenya}

Before the 2010 Constitution, Kenya was dualist. International treaties had to be domesticated through a national legislation to have legal effect in the country. All treaties ratified or assented to by the government had to be domesticated in order to apply as local law. For example, treaties such as the Convention on the Rights of the Child was domesticated as the Children's Act in order to apply in the country's legal order. In Okunda $v$ Republic, ${ }^{55}$ the High Court of Kenya limited the sources of law in Kenya to those listed under the Kenyan Judicature Act ${ }^{56}$ pursuant to Section 3 as among them the Constitution, Common Law, Doctrines of Equity, Statutes of General Application enforced in England on 12 August 1897. Further, the Court held that international law, not being one of the listed sources of law in the country, was not an independent force of law. The Court further stated that, unless domesticated through either a constitutional amendment or an Act of Parliament, international law had no legal effect in Kenya.

Similarly, in the 2001 case of Kamlesh Pattni \& Another $v$ Republic, ${ }^{57}$ the High Court held that, although international norms were persuasive, they could not apply directly to the country's legal order as the Constitution was supreme. The Court was alluding to the Universal Declaration of Human Rights (UDHR), the International Covenant on Civil and Political Rights (ICCPR) ${ }^{58}$ and the African Charter on Human and Peoples' Rights (African Charter). ${ }^{59}$ Subsequently, in East African Community v Republic, ${ }^{60}$ the Court held that international treaties that Kenya has ratified could only become part of the municipal law of Kenya if they are domesticated through legislation. Kenya therefore followed a strict dualist approach in implementing international law in its former constitution.

The promulgation of the 2010 Constitution of Kenya significantly altered the previous strict dualist approach. Article 2(1) of the Constitution states that the Constitution is the supreme law of the land. Ideally, this position would be at

\footnotetext{
Okunda v Republic (1970) KLR 457.

Judicature act Cap 8, Laws of Kenya.

Pattni and another $v$ Republic (2001), eKLR.

Acceded to by Kenya on 1 May 1972.

Ratified by Kenya on 10 February 1992.

East African Community v Republic (1970).
} 
odds with monism because in purely monist states, international law has a direct effect on a country's legal order and could supersede the country's constitution. Under Article 2(4), any law that contravenes the Constitution is void to the extent of that inconsistency. Article 2(5) allows general rules of international law to form part of the laws of Kenya, while Article 2(6) states that any treaty or convention ratified by Kenya shall form part of the law of Kenya under the Constitution. The use of 'under this Constitution' could still mean that the Constitution is supreme, as alluded to by Article 2(1) and therefore even the treaties that Kenya has ratified fall under the Constitution.

Towards this end, the Treaty Making and Ratification Act was enacted to provide for the procedure for ratifying treaties. ${ }^{61}$ The Act, as stated before, defines ratification as 'the international act by which the State signifies its consent to be bound by a treaty and includes acceptance, approval and accession where the treaty so provides'. ${ }^{62}$ The Act does not require an international treaty to be introduced to the Kenyan legal order through a national instrument such as an Act of Parliament. Instead, the Cabinet and Parliament are given responsibilities of ensuring that such treaty is consistent with Kenyan Constitution. ${ }^{63}$ After a treaty has been approved by the Cabinet, the Cabinet Secretary in charge must submit it together with a memorandum on it to the Speaker of the National Assembly. The relevant committee of the National Assembly, or both houses of the Parliament, depending on the nature of the treaty, shall ensure that there is public participation before approving it. ${ }^{64}$ This Act, therefore, provides that citizens must be involved in treaty making and ratification process. Conspicuously missing is the enactment of a national instrument to domesticate the treaty.

In Karen Njeri Kandie $v$ Alassane Ba \& another, ${ }^{65}$ the Supreme Court of Kenya declined to engage in the monist-dualist debate by holding that '... it is our view that the monist-dualist debate would not require our attention in this appeal, though the court may in the future be called upon, in appropriate circumstances, to make a firm finding on the issue...'. The Court of Appeal in this case had opined that Kenya was a dualist state in the old constitutional order but has since become a monist state under the new constitutional order. Although the Supreme Court declined to illuminate on this important legal conundrum, PLO Lumumba and Luis Franceschi have opined as follows: '...even when parliamentary

\footnotetext{
Long title, The Treaty Making and Ratification Act (Act No 45 of 2012).

Section 2(1), The Treaty Making and Ratification Act (Act No 45 of 2012).

Sections 5 and 6, The Treaty Making and Ratification Act (Act No 45 of 2012).

Sections 7 and 8, The Treaty Making and Ratification Act (Act No 45 of 2012).

Karen Njeri Kandie v Alassane Ba \& Shelter Afrique (2017) eKLR.
} 
approval may be called ratification, it should not be confused with the actual treaty ratification. ...Monism or dualism does not depend on the ratification processes but rather on the manner in which incorporation or domestication of a treaty takes place. ${ }^{36}$

There is nothing to show that Kenya is a purely monist system. Article 2(4), the supremacy clause, indicates that the Constitution is the supreme law of the land. In purely monist systems, international obligations may supersede national law, as the court in David Njoroge Macharia $v$ Republic appeared to suggest. ${ }^{67}$ In this case, the court noted that Kenya had previously adopted a dualist approach and, therefore, treaty provisions did not, as a general rule, have direct effect in domestic laws and courts. Proponents of the monist doctrine have noted that it would be impossible for monist states to adopt the entire international treaty into their municipal law, even where there is a constitution that is supreme. ${ }^{68}$ For this reason, O'Connell, for instance, has suggested that the best approach is to harmonise both the international treaty and the supreme law of the land so that a court will only apply the international treaty when it is consistent with the constitution. ${ }^{69}$ Such should be the Kenyan case, considering the supremacy clause in Article 2(4). ${ }^{70}$

Under the old constitutional order, Kenya had issues with implementing EAC Law, as shown in Okunda v Republic. ${ }^{71}$ In this case, the appellants had been prosecuted under the East African Community's Official Secrets Act of 1968. Section 8 (1) of the Act provided that the Secretary General of the Community had to be consulted before anyone was prosecuted under the Act. The Attorney General of the Republic of Kenya did not make such consultations because Section 26 (8) of the repealed Kenyan Constitution stated that the Attorney General was not subject to any directions in the exercise of his duties. The court held that the Attorney General did not break any law because the Constitution prevailed over any other law. An appeal at the Court of Appeal for East Africa was not successful. It was held that the Kenyan Constitution prevailed over any

66 Lumumba PLO, Franceschi L, The Constitution of Kenya, 2010: An introductory commentary, Nairobi, Strathmore University Press, 2014, 73.

67 David Njoroge Macharia v Republic (2011) eKLR.

68 Ludwikowski R, 'Supreme law or basic law? The decline of the concept of constitutional supremacy' Catholic University of America 9, 2001, 253-254.

69 O'Connell DP, 'The relationship between international law and municipal law' 14 Georgetown Law Journal 3, 1960, 431-440.

${ }^{70}$ Kabau T and Njoroge C, 'The application of international law in Kenya under the 2010 Constitution: Critical issues in the harmonisation of the legal system' 44 The Comparative and International Law Journal of Southern Africa 3, 2011, 293-310.

71 Okunda v Republic (1970) KLR 457. 
other law and that any other law which contravened the country's constitution was void.

Kenya domesticated the EAC Treaty through The Treaty for the Establishment of the East African Community Act in the year 2000. ${ }^{72}$ Section 8 of the Act provides that the Treaty and Acts of the Community have force of law in Kenya. Under the new constitutional dispensation and considering that the country has domesticated the EAC Treaty, there has not been much problem with implementing EAC Law in the country. In R $v$ Kenya Revenue Authority, exparte Mobamed Sheikh t/ a MSB Enterprises, ${ }^{73}$ for example, the High Court held that the East African Community Customs Management Act of 2004 prevailed over Kenya's Customs and Excise Act. ${ }^{74}$ The matter pertained to the importation of vehicles into the country. The court held that the EAC Customs Management Act was binding on Kenya as it sought to promote the affairs of the EAC Customs Union and, therefore, took precedence over the Kenyan Act in matters pertaining to customs. ${ }^{75}$ In addition, following the case of Prof Anyang' Nyong'o \& Others vs Attorney General of Kenya \& Others, ${ }^{76}$ which challenged the procedure that the country adopted in nominating its members to the EALA, the country revoked such a decision and actually elected its members, based on the ruling of the court.

Two factors are likely to have contributed to the reception of EAC Law by Kenya. First, the fact that Kenya changed from a strictly dualist system to a monist system, as shown in Article 2(6) of the Constitution, and recent case law could have contributed to the reception of EAC Law by the country's national legal order. This point is backed up by the fact that in the old constitutional order, EAC Law was not readily received by the country's legal order, as seen in the case of Okunda $v$ Republic. This paper, however, notes that Kenyan courts have not yet settled the question as to whether Kenya is a monist country or not. Second, the fact that Kenya domesticated the EAC Treaty through The Treaty for the Establishment of the East African Community Act could also have contributed to EAC Law being readily received by the country's legal order. The Act provides that the Treaty and Acts of the Community have legal force in the country. ${ }^{77}$

The Treaty for the Establishment of the East African Community (Act No. 2 of 2000).

73 Republic v Commissioner Customs and Excise Kenya Revenue Authority Exparte Mohamed Sheikh t/a MSB Enterprises (2012) eKLR.

74 Customs and Excise Act (2001)

75 In accordance with section 253 of the EAC Customs Management Act. See also the ruling of Majanja J in R $v$ Revenue Authority (2013) eKLR.

76 Professor Peter Anyang' Nyongo' and others v AG of Kenya and others (2007) EACJ Reference No 1 of 2006.

77 Article 8, The Treaty for the Establishment of the East African Community (Act No 2 of 2000). 


\section{ii. The Republic of Uganda}

As noted earlier, Uganda is the only EAC Partner State whose constitution recognises the need to promote regional integration as a foreign policy objective, although it does not specifically refer to the East African Community. ${ }^{78}$ Article 123(1) of the Constitution of Uganda of 1995 empowers the President or the President's delegate to ratify treaties. Article 123(2) empowers Parliament to enact laws pertaining to the ratification of treaties. The Ugandan Ratification of Treaties Act, ${ }^{79}$ under Section 2, stipulates two ways of ratifying a treaty, which would be determined by the nature of the treaty. Where the treaty pertains to armistice, neutrality or peace; or where the Attorney General has certified in writing that its implementation in Uganda would require an amendment to the Constitution; it is for Parliament to ratify such a treaty by resolution. However, where the treaty is not of this nature, the cabinet can ratify it without involving the Parliament. ${ }^{80}$ Section 6 of this Ugandan Act empowers the Minister responsible for foreign affairs, in consultation with the Attorney General, by statutory instrument make rules to standardise the treaty ratification process in the country. To date, these rules have not been made. Therefore, it is still not clear whether Uganda is a dualist or monist system. But, considering that the country adopted the commonwealth system in the same way as Kenya and noting that the law does not state otherwise, it is assumed by some that Uganda continues to be a dualist system. ${ }^{81}$ This cannot be said with authority, however, because the Constitution and the Ratification of Treaties Act do not require Parliament to enact a statute that domesticates treaties in the country, as is the case with dualist systems.

Regarding the implementation of EAC Law, Uganda domesticated the EAC Treaty through the East African Community Act, 2002. ${ }^{82}$ The applicability of EAC Law has been a subject for determination by Ugandan courts. For example, in Deepak. K Shah and Others $v$ Manurama Limited and Others, ${ }^{83}$ the defendants applied for security for costs, under the Ugandan Civil Procedure Rules, by the plaintiff (a Kenyan) as they were resident in Nairobi and their property was

\footnotetext{
Article XXVIII (iii) Constitution of the Republic of Uganda, 1995.

The Ratification of Treaties Act (1998).

Section 2, The Ratification of Treaties Act (1998).

See Fombad CM, 'Internationalization of Constitutional law and Constitutionalism in Africa, American Journal of Comparative Law 60, 2012, 447 and Oluoch LO, 'Legitimacy of the East African Community' 53 Journal of African Law 2, 2009, 214.

82 Sections 3(1) and 9, The East African Community Act (2002).

83 Deepak. K Shah and 3 others $v$ Mananura and 2 others (2002) eKLR.
} 
there. Ordinarily, the court would not have jurisdiction to enforce the judgment as the plaintiff was outside the court's jurisdiction. Ogoola J gave the matter an integrationist approach and declined to uphold the defendant's application. By so doing, the court gave EAC Law primacy over the domestic law of Uganda. The court held as follows:

'Art 104 of the Treaty provides for the free movement of persons, labour, services, and the right of establishment and residence. The Partner States are under obligation to ensure the enjoyment of these rights by their citizens within the Community. In this regard, the Court is mindful of the fact that the Treaty has the force of law in each Partner State (Art. 8 (2) (b)); and that this Treaty law has precedence over national law'. ${ }^{84}$

Similarly, in the case of Kamurali Jeremiah Birungi and Another $v$ The Attorney General of Uganda and Another, ${ }^{85}$ Musoke J acknowledged that Uganda was a signatory to the EAC Treaty and therefore the country was bound by the Treaty that it had already domesticated through an Act of Parliament. Additionally, in Yona Musinguzi v National Resistance Movement and Another, ${ }^{86}$ the court had been asked to issue an interim injunction to stop the Ugandan Parliament from electing its members for the EALA. Had the court issued the injunction, the country would not have sent representatives to EALA; yet, the deadline for doing so was approaching. Wolayo J held that Uganda had an obligation under the EAC Treaty to elect members to EALA and issuing such an injunction would be akin to going against the spirit of integration in the region. ${ }^{87}$

The High Court of Uganda expressed itself more firmly in the case of $L t$ Julius Kumanya $v$ Uganda Revenue Authority. ${ }^{88}$ In this case, the appellant argued that the Tax Appeals Tribunal denied him a tax refund for his imported vehicle. In his opinion, he should not have been taxed as he was a professional accountant in the Ugandan Army. ${ }^{89}$ The question was whether the provisions of the domestic legislation and rules were compatible with the provisions of the East African Community Management Act, 2004 (the EAC CMA). The EAC CMA did not have exemptions as part of the domestic legislation and applied equally to all citizens of the EAC. Considering the primacy of EAC Law over domestic law

\footnotetext{
Deepak K. Shah and Others v Manurama Limited and Others (2002) eKLR.

Kamurali v AG \& another (2013) eKLR.

Msuinguzi v National Resistance Movement \& anorther (2017) eKLR.

87 Section 50(1), East African Treaty (Act No. 2of 2000) and Section 4(2) East African Legislative Assembly Elections Act (2011).

88 Kamunya v Uganda Revenue Authority (2014) UGCOMMCC.

89 Section 97, Uganda People's Defence Forces Act, (2005) and Section 29, Uganda People's Defence Forces (Conditions of Service) (Officers) Regulations (S.I. 307-02).
} 
on matters such as the one before the Court. The Court held that the appellant was not entitled to any tax refund.

The upshot of this discussion is that Ugandan courts have upheld the doctrine of the supremacy of EAC Law on matters where EAC law has clearly stipulated that it takes precedence over the national law of Partner States.

\section{iii. Republic of Tanzania}

As for Tanzania, Article 63(3)(e) of the Constitution of the United Republic of Tanzania, 1977 provides that, for the purposes of performing its functions, the National Assembly may ratify all treaties and agreements to which the United Republic of Tanzania is a party and the provisions of which require ratification..$^{90}$ The Constitution does not state how international law and municipal law relate. The practice has been that international treaties have to be domesticated by an Act of Parliament for them to have legal force in the country.

Regarding EAC Law, Tanzania domesticated the EAC Treaty through the Treaty for the Establishment of the East African Community Act, 2001. Acts of the Community have legal force in Tanzania mainland and also Zanzibar. ${ }^{11}$ It appears that in Tanzania's legal order only Acts of the Community, referring to the laws enacted by the EAC, have legal force in the country. It would also appear that the EAC Treaty does not have legal force in the country's legal order. If that is the case, the Act could inhibit the effective implementation of EAC Law in Tanzania, considering that the country is practically a dualist system. The Act does not state either the legal effect of decisions of EAC organs, including decisions of the Summit and those of the EACJ. However, superior courts in Tanzania appear to be willing to provide interpretations that give legal effect to the EAC Treaty in Tanzania. In the case of East African Development Bank v Blueline Enterprises $L t d,{ }^{92}$ the Court of Appeal of Tanzania held that the EAC Treaty is part of Tanzania's municipal laws, having been domesticated by Tanzania through an Act of Parliament.

Article 63(3)(e), The Constitution of the United Republic of Tanzania, (1977).

Section 8, Establishment of the East African Community Act (Act No. 2 of 2000).

East African Development Bank v Blueline Enterprises Ltd (2011) Court of Appeal of Tanzania. 


\section{iv. Republic of Rwanda}

Article 95 of the Constitution of the Republic of Rwanda of 2003 that was revised in 2015 outlines the hierarchy of laws in the country's legal order. From top to bottom, the Article lists the laws as: Constitution, organic law, international treaties and agreements ratified by Rwanda, ordinary law and orders. A law cannot contradict another law that is higher in the hierarchy. ${ }^{93}$ For this reason, international treaties and agreements cannot contradict the Constitution or organic law. Organic laws are those that are designated as such and empowered by the Constitution to regulate other matters in the place of the constitution. The President or the President's delegate is empowered to ratify treaties after which he or she will inform Parliament after the conclusion of the treaty. However, international treaties and agreements concerning armistice, peace, commerce, accession to international organisations, those which commit state finances, and those requiring modification of national legislation or relating to the status of persons can only be ratified after approval by Parliament. ${ }^{94}$

Once published in the official gazette, international treaties and agreements that Rwanda has ratified have the force of law in the country's legal order, subject to the hierarchy of laws as underlined in Article 95 of the Constitution. ${ }^{95}$ In the event that an international treaty or agreement contains provisions which are conflicting with the Constitution or an organic law, they cannot be ratified until the Constitution or the organic law is amended. ${ }^{96}$ What this means is that international treaties that Rwanda has ratified have legal force in the country's legal order if they do not contravene the other laws that are above them in the hierarchy. This effectively makes Rwanda a monist state. It is also interesting to note that the Constitution and organic laws could be amended to accommodate an international treaty or agreement. ${ }^{97}$

The Supreme Court of Rwanda has expressed its reception of EAC Law in the country's legal order. In Autoxpress Sarl v Rwanda Revenue Authority, ${ }^{98}$ the appellant was accused by the Rwanda Revenue Authority of under-declaring the value of their imported vehicle, causing them to pay less tax. The EAC Customs Management Act, 2004 proscribes such conduct and renders it an

\footnotetext{
Article 95, The Constitution of the Republic of Rwanda, (2003).

Article 167, Constitution of the Republic of Rwanda (2005).

Article 168, Constitution of the Republic of Rwanda (2015).

Article168, Constitution of the Republic of Rwanda (2015).

97 Sebijjo E, Regional Integration Law in the East African Community and the European Union, Centre for Law, Economics and Policy on East African Integration, (2018).

98 Autoxpress Sarl v Rwanda Revenue Authority (2016) 1 RLR.
} 
offence. Rwandan national law also makes it an offence to under-declare import value. The authority therefore ordered the appellant to pay the evaded tax and a fine. Under the EAC CMA, 2004, such an order can only be made once the appellant has admitted the offence. It can also only be made outside court process. The Supreme Court of Rwanda therefore applied the EAC CMA, 2004 to nullify an order made under municipal law of Rwanda. It therefore appears that implementing EAC Law in Rwanda is not problematic, as the country's constitution is clear that international law has legal force in the country, provided it does not contravene the laws that are above it in the hierarchy.

\section{v. Republic of Burundi}

The Constitution of the Republic of Burundi of 2005 empowers the President to sign and ratify treaties. ${ }^{99}$ A certain category of treaties cannot be ratified unless there is a law providing for their ratification. These are treaties that fall under either of these categories: treaties of peace and commerce, treaties relating to international organisations, treaties that engage the finances of the state, those that modify a legislation, and those that relate to the status of persons. ${ }^{100}$ Ideally, such treaties cannot have the force of law in Burundi unless they have been domesticated by a national law. This implies that Burundi is partly dualist and partly monist as certain treaties can directly have legal force in the Burundian legal order while others have to be domesticated through a national law. The EAC Treaty does not fall under these categories. In effect, it does not need domestication through a national instrument.

\section{vi. Republic of South Sudan}

The National Parliament of the Republic of South Sudan has power to ratify treaties. ${ }^{101}$ South Sudan's foreign policy seeks to achieve such objectives as the promotion of international cooperation, the achievement of economic integration, the enhancement of respect for human rights, the promotion of dialogue among civilisations, and the respect for international law and treaty obligations. ${ }^{102}$ Having been the latest member to accede to the EAC Treaty, a lot more remains to be seen in the continent's newest republic. ${ }^{103}$

\footnotetext{
Article 289, Constitution of the Republic of Burundi (2005).

Article 290, Constitution of the Republic of Burundi (2005).

Article 57, Transitional Constitution of the Republic of South Sudan (2011).

Article 43, Transitional Constitution of the Republic of South Sudan (2011).

South Sudan acceded to the EAC Treaty on Friday 15th April 2016.
} 


\section{Implementing EAC Law in National Legal Systems}

The EAC Treaty is not luminous enough on how EAC law should be implemented in Partner States' legal systems. But, the EACJ has interpreted the EAC Treaty in a manner that ensures that national courts of Partner States apply the provisions of the Treaty when litigants appear before them. Whereas it is the EACJ that has jurisdiction to interpret the EAC Treaty, ${ }^{104}$ the Court has previously held that national courts can directly apply the Treaty in their jurisdictions. The Court does not, however, have jurisdiction to interpret the Treaty where such jurisdiction is conferred on courts of Partner States. ${ }^{105}$

National courts of Partner States also have the power to interpret and apply the EAC Treaty under Article 33 of the Treaty, although decisions of the EACJ have precedence over those of national courts on a similar matter. ${ }^{106}$ National courts and tribunals can also ask the EACJ for a preliminary ruling where they are faced with a question regarding the interpretation of the Treaty. This ensures that the Treaty is interpreted in a uniform manner by the EACJ. The preliminary ruling only acts as a guide. It is not binding on a national court with reference to which it is made. The national court will only apply the ruling where it is satisfied that the ruling informs the court in delivering the final judgment. For example, in East African Center for Trade Policy $v$ The Secretary General of the East African Community, ${ }^{107}$ the Court opined that national courts have jurisdiction over the interpretation and application of the Treaty.

Preliminary rulings ensure that national courts of Partner States facilitate Partner States' respect for Community law. For example, in Firma Foto-Frost $v$ Hauptrollamt Lubeck-Ost, ${ }^{108}$ the European Court of Justice held that requests for preliminary rulings enable regional courts to affirm the respect of Partner States' institutions for community law. In this case, a German Court wanted to know whether it could declare the decision of the European Commission in external trade invalid. The Court held that it was not possible for national courts to do so since the matter of invalidating community law fell under the jurisdiction

\footnotetext{
104 Article 27(1), Treaty for the Establishment of the East African Community (Act No. 2 of 2000).

105 One of the amendments to the Treaty that was initiated by the Summit following the judgment of the Court in the case Professor Peter Anyang' Nyongo' and others v AG of Kenya and others (2007) EACJ Reference No 1 of 2006.

106 Article 33(2), Treaty for the Establishment of the East African Community (Act No. 2 of 2000).

107 The East African Centre for Trade Policy and Law v The Secretary General of the East African Community (Reference No. 9 of 2012).

108 Foto-Frost v Hauptzollamt Lübeck-Ost (1987).
} 
of the CJEU. The Court also opined that it was its responsibility to ensure that Community law was implemented uniformly within the Community and, therefore, any divergences in the interpretation of Community law by national courts of Partner States would place Community law in jeopardy because of the attendant legal uncertainties.

The decision to refer matters for interpretation in regional courts must, however, emanate from the national court. In Arsenal Football Club plc v Reeds, ${ }^{109}$ the CJEU held that the decision as to whether or not to refer a matter to the Community Court is either discretionary or mandatory, depending on the circumstances. By discretionary, it means that the national court may decide whether to refer the matter to the Community Court or not. By mandatory, it means that the national court does not have an option but to refer the matter to the Community Court. Further, the Court stated that the national court or tribunal is the one to make the reference on its own motion (suo motu) and not the parties to the case to move it.

According to the Court, there are three instances where it is not necessary for the national court or tribunal to refer the matter to the CJEU. The first instance is when the matter that is the subject of reference does not involve community law. The second instance is when the CJEU has previously determined a similar question and, therefore, the previous determination of the similar question is still applicable. Thirdly, it is not necessary to refer the matter for interpretation by the CJEU where the expected interpretation is so obvious that there is no reasonable doubt left requiring the input of the CJEU. ${ }^{110}$

The practice in the CJEU has been that a question can be referred for a preliminary ruling if it meets three criteria. First, the point raised must be a conclusive one. Secondly, previous rulings on the same subject matter are still relevant to the national court, and that the national court or tribunal should only resubmit the matter if it thinks that the ruling was wrongly issued. Third, there is no need to request a preliminary ruling if the provision is reasonably clear and free from doubt since 'it constitutes an 'acte clair" ${ }^{111}$ and all that is expected of the court or tribunal is to apply it. ${ }^{312}$

\footnotetext{
Arsenal Football Club plc v Reeds (2003) ALL ER 137.

Article 34, Treaty for the Establishment of the East African Community (Act No. 2 of 2000).

11 That is to say, the correct interpretation of Treaty law is obvious. Acte clair is a doctrine of European Union law, which states that if a judgment or rule of law is clear enough, then a member state has no duty to refer a question for preliminary ruling to the Court of Justice of the European Union.

112 Bulmerv Bollinger (1974).
} 
Rule 76 of the EACJ Rules of Procedure ${ }^{113}$ sets the form that preliminary rulings should take. A request by a national court pertaining to Article 34 of the Treaty must be lodged in the Appellate Division of the Court in accordance with the procedure that the Rules set out in the Sixth Schedule. ${ }^{114}$ The request must specify the question raised and the issues that need to be determined by the Court. ${ }^{115}$ The Court shall then determine the issues and communicate its determination to the national court or tribunal as soon as it has reached the decision. ${ }^{116}$

The Sixth Schedule sets out the procedure to be followed when referring a matter to the Court for a preliminary ruling. It is the national court or tribunal that is supposed to notify the Court about the issues requiring a preliminary ruling. ${ }^{117}$ The Registrar of the Court shall then notify the parties, the Secretary General to the Community and the organ or institution of the Community whose act precipitated the current request for a preliminary ruling. ${ }^{118}$ These parties, including the organ or institution of the Community where applicable and the Secretary General shall file statements to the Court within two months after being notified. ${ }^{119}$ The Court may also request clarification from the national court or tribunal that requested the preliminary ruling. ${ }^{120}$ The Registrar shall notify all parties to the reference and also the national court or tribunal after the Court has issued its reasoned ruling on the question. ${ }^{121}$

Referring a matter for a preliminary ruling to the Court enhances the cooperation between the Court and national courts and also ensures a uniform interpretation of community law by all Partner States. Proceedings in the national court or tribunal must, then, be stayed, pending the determination of the Court on the preliminary question raised. When this happens, the national court or tribunal may rule on protective measures to preserve the status quo of the case pending before it. Proceedings on preliminary rulings do not give rise to costs. It is for the national court or tribunal to rule on costs and not the EACJ. ${ }^{122}$

113 The East African Community Legal Notices Supplement No. 1 to the East African Community, Gazette No. 7 of 11 April 2013.

114 Rule 76(1), East African Court of Justice Rules of Procedure (2013).

115 Rule 76(2), East African Court of Justice Rules of Procedure (2013).

116 Rule 76(3), East African Court of Justice Rules of Procedure (2013).

117 Schedule 6, paragraph 1, East African Court of Justice Rules of Procedure (2013).

118 Schedule 6, paragraph 2, East African Court of Justice Rules of Procedure (2013).

119 Schedule 6, paragraph 3, East African Court of Justice Rules of Procedure (2013).

120 Schedule 6, paragraph 10, East African Court of Justice Rules of Procedure (2013).

121 Schedule 6, paragraph 9, East African Court of Justice Rules of Procedure (2013).

122 The East African Court of Justice Guidelines on a Reference from National Courts for a Preliminary Ruling - < $\underline{\text { http://eacj.org/wp-content/uploads/2012/08/Guidelines-Reference-for-Preliminary- }}$ 
In Attorney General of the Republic of Uganda v Tom Kyahurwenda, ${ }^{123}$ the High Court of Uganda referred two questions for a preliminary ruling by the Court. In the High Court case between Tom Kyahurwenda and the Attorney General of the Republic of Uganda, Tom Kyahurwenda, a former Member of Parliament in Buhanguzi County in the Republic of Uganda, sued the government at the High Court for malicious prosecution for the alleged murder of his sister, Margaret Nusungwa. ${ }^{124} \mathrm{He}$ sought compensation from the government on the basis that the prosecution had cost him his parliamentary seat in the elections. As a result, he asked the High Court to rule that the government of Uganda had violated Articles 6, 7, 8, and 123 of the EAC Treaty. Thus, he sought reparation in form of damages for the loss and injury that he suffered in the hands of government operatives during the malicious arrest and prosecution. Article 6 of the EAC Treaty relates to the fundamental principles of the Community while Article 7 focuses on the operational principles of the Community. Article 8 pertains to the general undertaking of Partner States as to the implementation of the Treaty, while Article 123 relates to cooperation of Partner States of the EAC in political matters.

The first question that the High Court of Uganda referred to the EACJ was whether Articles 6, 7, 8, and 123 as read together with Articles 27 and 33 of the Treaty can be determined by national courts. The second question was whether Articles 6, 7, 8, and 123 as read together with Articles 27 and 33 of the Treaty are self-executing and confer jurisdiction upon national courts to determine matters of Treaty violations, and also award damages to the applicants. The Court reformulated the questions as 'by what court(s) should the Treaty be interpreted?' The EACJ held that national courts have the jurisdiction to apply the provisions of the Treaty as provided for under Article 33 and 34 of the Treaty and that the preliminary ruling procedure in Article 34 should be based on the interpretation of the provisions of the Treaty and not their application. The Court further held that the discretion conferred on national courts by Article 34 of the Treaty is narrow because it is restricted to deciding whether it is necessary to refer the question before the court for interpretation by the EACJ. Once it determines that it is necessary, the national court or tribunal has no option but to refer the question to the EACJ for interpretation of the relevant Treaty provisions.

Ruling.pdf > on March 6, 2017.

123 The Attorney General of the Republic of Uganda v Tom Kyahurwenda (No. 1 of 2014).

124 Tom Kyaburwenda v The Attorney General of Uganda (2012) High Court of Uganda at Kampala. 
The EACJ in this case also determined that a preliminary ruling on a particular question of the Treaty is binding on the national court or tribunal that requested the ruling and also erga omnes, for instance, to all national courts and tribunals of Partner States. Further, the Court held that, whereas national courts and tribunals of Partner States have jurisdiction to apply the Treaty and to award relevant damages, it is only the EACJ that has the exclusive jurisdiction to interpret the Treaty and invalidate Community acts.

Article 54 of the Protocol Establishing the East African Common Market, 2010 states as follows:

'Partner States guarantee any person whose rights and liberties as recognised by this Protocol have been infringed upon, shall have the right to redress, even where this infringement has been committed by persons acting in their official capacities; and the competent judicial, administrative or legislative authority or any other competent authority, shall rule on the rights of the person who is seeking redress'.

The Protocol therefore gives national courts power to rule on the rights of citizens of the EAC regarding the affairs of a common market. Therefore, aggrieved citizens do not have to always approach the EACJ to have their disputes resolved. This Article has been a subject of interrogation by the EACJ in the past. In the case of The East African Law Society $v$ The Secretary General of the East African Community, ${ }^{125}$ the EACJ was asked to declare that Article 54 (2) of the Common Market Protocol which conferred jurisdiction relating to disputes arising from the Protocol to national courts of Partner States ousted the jurisdiction of the EACJ in such matters. It was also asked to determine whether it created a parallel dispute resolution mechanism. The Court held that although the Article empowers national courts to deliver justice in terms of redress to individuals whose rights under the Protocol have been infringed upon, it does not oust the jurisdiction of the Court over the interpretation of the Protocol.

The developing body of jurisprudence both by the EACJ and national courts of Partner States shows that Community norms can easily be transposed into the national legal order of Partner States. ${ }^{126}$ Citizens of any Partner State of the EAC can pursue their rights under the EAC Treaty, Protocols and other Community instruments in national courts. National courts have been receptive of such matters and have been willing to interpret the EAC Treaty in a manner that grants those rights.

\footnotetext{
125 East African Law Society v The Secretary General of the East African Community (Reference No. 1 of 2011).

126 Gathii J, African Regional Trade Agreements as Legal Regimes, Cambridge University Press, 2011, 199.
} 


\section{Conclusion}

The EAC Treaty vaguely states how EAC law would be implemented in Partner States' national legal order. Since it is a subset of international law, the implementation of EAC law in Partner States' jurisdiction is subject to the constitutional philosophies of these states. The national legal order of countries that are dualist accept international law as part of the body of laws governing the countries. It has not, however, been easy for these countries to implement EAC law and the EACJ has been called upon in several instances to deliver rulings that give effect to the supremacy and direct effect of EAC law in Partner States' jurisdictions. One way of giving effect to EAC Law in these countries is by cementing it in the constitutions of these Partner States. National courts should also play a key role by interpreting EAC Law to give it a direct effect in national jurisdictions so that the objectives stated in Article 5 of the Treaty can be achieved. Uganda is dualist; but, it is the only EAC Partner State whose constitution mentions regional economic integration as a foreign policy that the country is willing to pursue. There are also several instances in which Ugandan superior courts have held that EAC Law has primacy over the national law of Uganda. Tanzania is dualist and has shown strong resistance to the concepts of supremacy and direct effect of EAC law in the country's national legal order. The EACJ has, however, come out strongly to rule that Tanzania domesticated the EAC Treaty and cannot therefore run away from its responsibilities.

Burundi is partly monist and partly dualist. There are those treaties that have legal force in the country without the need for a domesticating Act. However, other treaties have to be domesticated to have legal force in the country.

Article 3 of the Transitional Constitution of the Republic of South Sudan states that the Constitution is supreme and that all other laws shall conform to the Constitution. Article 43 on foreign policy, however, confirms that the country is willing to implement foreign policy that promotes international cooperation, achieves African economic integration, enhances respect for human rights, promotes dialogue among civilisations, respects international law and treaty obligations, and enhances economic cooperation of countries in the region. This shows why South Sudan acceded to the EAC Treaty. As the youngest member of the EAC, the country has not yet developed strong legal relationships with the EAC. More research is required to establish the relationship between the law of South Sudan and EAC Law. As the Community gears towards establishing a political federation, a lot more needs to be done to streamline the implementation of Community law in Partner States jurisdictions. 